\title{
Qualitative analysis of pea (Pisum sativum) seeds procured from different sources and locations of district Haripur- Khyber Pukhtunkhwa Pakistan
}

\author{
Muhammad Irshad Khan ${ }^{1}$, Shah Masaud Khan ${ }^{1}$, Ijaz Hussain, Shams ur \\ Rehman $^{2 *}$, Syed Hassan Raza Shah ${ }^{3}$, Qasim Ayub ${ }^{1}$ and Naveed ul Haq ${ }^{2}$ \\ 1. Department of Horticulture, The University of Haripur-Pakistan \\ 2. Department of Food Science and Technology, The University of Haripur-Pakistan \\ 3. Department of Plant Breeding and Genetics, The University of Haripur-Pakistan \\ *Corresponding author's email: Sr_awan1@yahoomail.com \\ Citation \\ Muhammad Irshad Khan, Shah Masaud Khan, Ijaz Hussain, Shams ur Rehman, Syed Hassan Raza Shah, Qasim \\ Ayub and Naveed ul Haq. Qualitative analysis of pea (Pisum sativum) seeds procured from different sources and \\ locations of district Haripur-Khyber Pukhtunkhwa Pakistan. Pure and Applied Biology. Vol. 8, Issue 2, pp1782- \\ 1788. http://dx.doi.org/10.19045/bspab.2019.80121
}

Received: 19/03/2019 Revised: 20/06/2019

Accepted: 26/06/2019

Online First: 29/06/2019

\section{Abstract}

This research was conducted in the District of Haripur (Haripur, Khanpur and Ghazi) to increase the yield of pea. Pea seeds were collected from three sources (Farmer, Dealer and Government Organization) from each location in order to investigate the yield traits. Mean values for yield traits of pea seeds were found to be, Embryo damaged Seed $0.77 \%$ to $3.31 \%$, inert matter $0.02 \%$ to $5.06 \%$, moisture level $7.43 \%$ to $6.05 \%$, seed Germination $67 \%$ to $91.66 \%$, insect affected seeds $15.33 \%$ to $4 \%$, stones and dust particles $32.33 \%$ to $9 \%$, viability $87.33 \%$ to $55.33 \%$, other variety seed $1.34 \%$ to $0 \%$, other crop seed $5.65 \%$ to $0 \%$ and seed purity (\%) were $98.4 \%$ to $78.8 \%$ for pea seeds collected from haripur, khanpur and ghazi. Seeds collected from Khanpur region possess best seed quality traits. Overall; seed quality of Government organization possesses desirable seed quality and suggested to grow for better yield. Pea farmers of district Haripur should be trained to use lasted techniques of seed storage to minimize the economic losses caused due to inferior quality seeds.

Keywords: Locations; Pea; Quality traits; Seed yield

\section{Introduction}

Pea (Pisum sativum L.) is a leguminous crop belongs to the family leguminoseae. Peas are the most common nutritious vegetable crop and mainly cultivated as a winter crop in all over the world. It is chiefly a cash crop of the world and consisting to around $40 \%$ of the total trading in pulses [1]. The seed of the pea plant is small and spherical in shape. Seeds are present in the pod and each pod consists of many seed which are either green or yellow in color. Botanically pea pods are fruit since they are developing from the ovary of the pea flower [2]. Peas are widely grown in the tropical as well as subtropical countries like Pakistan, India, Burma, Equator and Colombia [3]. 
Peas have been cultivated throughout the country. In KPK (Khyber Pakhtunkhwa) peas occupy an area of 1942 hectares with a total production of 13418 tones. The sites of cultivation in Khyber Pakhtunkhwa are Haripur, Mansehra, Swabi etc. Hazara division enjoyed the central position in Khyber Pakhtunkhwa by supplying peas [4]. Peas are starchy in nature and contains high amount of fiber, vitamins and minerals like Phosporous, copper, iron, zinc and manganese. Sugar rate in grains are high in pea crop, dry weight is around one quarter sugar and one quarter protein [5] Peas consist of higher amount of protein with essential amino acid specially lysine [3]. Pea plant plays an important role in human and animal nutrition because of high protein level (23 $33 \%)$ [4].

Minimum plant germination occurs at soil temperature ranges from 4 to $6^{\circ} \mathrm{C}$ while optimum plant germination occurs at 16 to 18 ${ }^{\circ} \mathrm{C}[6]$. High soil temperature leads to very poor emergence of the seed. Pea crop can withstand some frost before blooming, but flowers and pods of pea crop are susceptible to chilling temperature. A regular supply of water promotes high yield but root rot induces at extensive rainfall [7]. Pea cultivar performs differently under different agroclimatic conditions of the region and various cultivars of same species even grown in same environment conditions often have differences in yield. Yield and quality characteristics are very complex traits in pea crop depending on certain biological factors

Table 1. Sources of pea seeds between environment and heredity. The combination of traits and characteristics of cultivars differ according to agro-climatic conditions of the region [8].

Pea crop is cultivated for a lot of reasons and purposes, the main purpose of growing pea crop is to obtain abundant robust product. Pea grains are consumed fresh or processed as canned food. Pea plants are also used to feed animals. In spite of large number of cultivars in the field, pea yield per unit is lower than international standard in Pakistan including many factors like poor cultural practices, poor weed control, pest attack, etc. Amongst these pests, incidence of diseases also plays a major role in the low yield. The crop has a very promising future due to its shorter life span and high yield capacity and efforts should be made to increase yield by selecting high quality seed for cultivation that meet with the market standards and are adaptable to our climatic conditions. Hence current study was conducted to identify suitable location for pea seed procurement among different locations of Haripur and to select and identify suitable source for pea seed procurement in district Haripur.

\section{Materials and methods}

This research was conducted in the Department of Horticulture in the University of Haripur.

\section{Sample collection}

Pea seed samples were collected from farmer, dealer and government organization from the locations of Khanpur, Haripur and Ghazi (Table 1).

\begin{tabular}{|c|c|l|}
\hline S. No. & Codes & \multicolumn{1}{c|}{ Sources } \\
\hline 1 & $\mathrm{~T}_{1}$ & Pea Seed collected from farmer, Khanpur \\
\hline 2 & $\mathrm{~T}_{2}$ & Pea Seed collected from Dealer, Khanpur \\
\hline 3 & $\mathrm{~T} 3$ & Pea seed collected from Government Organization, Khanpur \\
\hline 4 & $\mathrm{~T}_{4}$ & Pea seed collected from farmers, Haripur \\
\hline 5 & $\mathrm{~T}_{5}$ & Pea seed collected from Dealer, Haripur \\
\hline 6 & $\mathrm{~T}_{6}$ & Pea seed collected from Government Organization, Haripur \\
\hline 7 & $\mathrm{~T}_{7}$ & Pea seed collected from farmers, Ghazi \\
\hline 8 & $\mathrm{~T}_{8}$ & Pea Seed collected from Dealer, Ghazi \\
\hline 9 & $\mathrm{~T}_{9}$ & Seed collected from Government Organization, Ghazi \\
\hline
\end{tabular}




\section{Yield Traits analysis}

Analysis of Embryo damaged Seed (\%), inert matter (\%), moisture level (\%) seed Germination (\%), insect affected seeds $(\%)$ stones and dust particles $(\%)$, viability $(\%)$, other variety seed (\%), other crop seed $(\%)$ and seed purity $(\%)$ were carried out on pea seeds collected from all the locations as prescribed in [6]

\section{Statistical analysis}

Data were collected and analyzed by using one way ANOVA (analysis of variance) and means were separated by LSD (Latin Square Design) test at 5\% probability level to compare the difference among treatments means [9].

\section{Result and discussion}

Mean values for Embryo damaged Seed (\%), inert matter $(\%)$, moisture level $(\%)$ seed Germination (\%), insect affected seeds (\%) were present in (Table 2). Results revealed that there is significant difference were present between different locations and sources. Seeds collected from all the sources shows that embryo damaged seeds were in the range of $0.77 \%$ to $3.31 \%$, inert matter were in the range of $0.02 \%$ to $5.06 \%$, moisture level content were in close range of $7.43 \%$ to $6.05 \%$, seed germination percentage were in the range of $67 \%$ to $91.66 \%$, insect affected seeds were in the range of $15.33 \%$ to $4 \%$.

Results showed that Pea seed collected from farmers, contained highest percentage of damaged embryo (3.31\%) followed by pea seed collected from dealers of Khanpur $(3.19 \%)$, while lowest percentage of damaged seed $(0.07 \%)$ were found in pea seed collected from government organization of Khanpur. seeds procured from government organization of Haripur contained the highest value of inert matter $(5.06 \%)$ followed by pea seed collected from farmers of Haripur (3.33\%). The mean values also revealed that lowest percentage of inert matter was found in pea seed collected from government organization of Khanpur $(0.02 \%)$. government organization of Khanpur contained the highest percentage of moisture content $(7.43 \%)$ followed by pea seed collected from dealer of Khanpur (7.26\%), while the lowest percentage of moisture level was found in pea seed collected from government organization of Ghazi $(6.26 \%)$. government organization of Khanpur and Haripur showed the highest germination percentage $(91.66 \%)$ while lowest percentage of germination was found in pea seed collected from farmer of Ghazi (67\%). Pea seeds which were collected from farmer of Ghazi contained the highest percentage of insect affected seeds.

The results of the present study were in-line with the findings of $[1,5,10-12]$. Embryo damaged seed significantly affect the overall yield of the crop. Damaged Seed found to be very low in the seeds collected from government organization because government organization produces pure seed and maintained high quality with good germination rate. The damaged seeds were recorded high in the seed collected from famers and it was because farmer had fewer facilities regarding seed grading, and has poor storage conditions [13]. Similarly, farmers commonly use inferior quality seeds for sowing hence an increase in damaged seed occur. The seeds which were collected from the Government Organization contain low amount of inert matter as it was the fact that Government Organization seed was pure due to proper seed handling, seed grading and development. Farmers and dealers seed contains high amount of inert matter as both of them uses local management practices of seed collection and cleaning [14]. The high percent of moisture in farmer's seed can be due to fact that farmers use ordinary containers for seed packing and seed storage, these containers have thousands of small pores due to its nature of preparation that results in absorption of moisture from the 
atmosphere. [14, 15] reported that the seeds absorbed moisture when they were stored in ordinary containers. As seed is highly hygroscopic living material; it absorbs moisture from air if it is stored in an environment where relative humidity is higher than seed moisture content [12]. The humidity during the months of June and July was high during the Monsoon season which allows the seeds to absorb moisture due to improper storage practices. For this reason, seeds absorbed moisture from the ambient air and tended to equilibrium with relative humidity.

Table 2. Mean and LSD values of treatment for embryo damaged seed, inert matter, moisture level, seed germination and insect affected seeds

\begin{tabular}{|c|c|c|c|c|c|}
\hline $\begin{array}{c}\text { Seed } \\
\text { Sources }\end{array}$ & $\begin{array}{c}\text { Embryo Damaged } \\
\text { Seed }(\%)\end{array}$ & $\begin{array}{c}\text { Inert matter } \\
(\%)\end{array}$ & $\begin{array}{c}\text { Moisture level } \\
(\%)\end{array}$ & $\begin{array}{c}\text { Seed Germination } \\
(\%)\end{array}$ & $\begin{array}{l}\text { Insect Affected } \\
\text { Seeds }(\%)\end{array}$ \\
\hline $\mathrm{T} 1$ & $2.76 \mathrm{~d} \pm 0.1$ & $2.09 \mathrm{~cd} \pm 0.0$ & $6.60 \mathrm{bc} \pm 0.3$ & $73.3 \mathrm{~cd} \pm 6.4$ & $10.0 \mathrm{bc} \pm 5.0$ \\
\hline $\mathrm{T} 2$ & $3.19 \mathrm{~b} \pm 0.1$ & $0.18 \mathrm{~g} \pm 0.0$ & $7.26 \mathrm{a} \pm 0.2$ & $80.6 \mathrm{bc} \pm 8.1$ & $9.33 b c \pm 3.0$ \\
\hline T3 & $0.71 \mathrm{f} \pm 0.1$ & $0.02 \mathrm{~g} \pm 0.0$ & $7.43 \mathrm{a} \pm 0.2$ & $91.6 \mathrm{a} \pm 4.0$ & $4.00 \mathrm{~d} \pm 1.0$ \\
\hline $\mathrm{T} 4$ & $3.07 \mathrm{c} \pm 0.0$ & $3.33 \mathrm{~b} \pm 0.2$ & $6.60 \mathrm{bc} \pm 0.3$ & $85.3 \mathrm{ab} \pm 3.0$ & $14.0 \mathrm{ab} \pm 3.6$ \\
\hline T5 & $0.33 \mathrm{~h} \pm 0.0$ & $2.2 \mathrm{c} \pm 0.1$ & $6.73 b \pm 0.2$ & $71.6 \mathrm{~cd} \pm 4.0$ & $10.6 a b c \pm 2.5$ \\
\hline T6 & $1.17 \mathrm{e} \pm 0.0$ & $5.06 \mathrm{a} \pm 0.1$ & $6.56 b c \pm 0.1$ & $91.6 \mathrm{a} \pm 4.0$ & $7.33 \mathrm{~cd} \pm 1.5$ \\
\hline $\mathrm{T} 7$ & $3.31 \mathrm{a} \pm 0.1$ & $2.01 \mathrm{~d} \pm 0.1$ & $6.56 b c \pm 0.1$ & $67.0 \mathrm{~d} \pm 7.2$ & $15.3 \mathrm{a} \pm 3.0$ \\
\hline T8 & $0.55 \mathrm{~g} \pm 0.0$ & $1.61 \mathrm{e} \pm 0.1$ & $6.5 \mathrm{bc} \pm 0.2$ & $77.0 \mathrm{bc} \pm 8.0$ & $9 c \pm 4.5$ \\
\hline T9 & $0.77 \mathrm{f} \pm 0.0$ & $1.05 \mathrm{f} \pm 0.0$ & $6.26 \mathrm{c} \pm 0.2$ & $86.0 \mathrm{ab} \pm 5.2$ & $8.33 \mathrm{~cd} \pm 5.0$ \\
\hline
\end{tabular}

Seed germination rate was high in the seeds procured by government organizations of Haripur and Khanpur which is due to use of modern practices of seed selection, grading and the use of high quality seed which ensures that seeds possess good quality and health. It was also due to the development of good quality seed with high rate of seed germination. Farmers and dealers seed recorded low germination percentage due to the use of inferior quality of crop for sowing and old cultural practices $[5,11]$. The insects invade seeds in the field during seed development or during processing on the threshing floor. However, these insect may be destroyed if well sun dried or properly treated with insecticide before storage [12]. Mean values for stones and dust particles $(\%)$, viability $(\%)$, other variety seed $(\%)$, other crop seed (\%) and seed purity (\%) were present in (Table 3). Results revealed that there is significant difference were present between different locations and sources. Seeds collected from all the sources show that stone and dust particles (\%) were in the range of $32.33 \%$ to $9 \%$, Viability (\%) were in the range of $87.33 \%$ to $55.33 \%$, other variets seed $(\%)$ were in the range of $1.34 \%$ to $0 \%$, other crop seed $(\%)$ were in the range of $5.65 \%$ to $0 \%$ and seed purity $\% 0$ were in the range of $98.4 \%$ to $78.8 \%$.

Results showed that pea seed collected from farmer of Ghazi contained the highest percentage of stones and dust particles $(32.33 \%)$ followed by pea seed collected from farmers of Haripur (27.66\%), while the lowest percentage of stones and dust particles were found in pea seed collected from government organizations of Khanpur (9\%). Results showed that pea seed which were collected from government organization of Haripur contains the highest percentage of viability $(87.33 \%)$ followed by seeds collected from government organization of 
Khanpur (84.33\%), while lowest percentage of viability test was found in pea seed collected from farmers of Ghazi $(55.33 \%)$. Results showed that pea seeds collected from farmers of Khanpur contains highest amount of other variety seeds (1.34\%) followed by pea seed collected from farmers of Ghazi $(0.6 \%)$, while lowest percentage of other variety seeds $(0.0 \%)$ were found in pea seed collected from government organization of Khanpur, Haripur and Ghazi. Results of mean values showed that pea seed collected from government organization of Ghazi contains the highest amount of other crop seeds $(5.65 \%)$ followed by pea seed collected from farmers of Ghazi $(0.58 \%)$ and pea seed collected from dealers of Haripur $(0.33 \%)$ while lowest value of other crop seeds $(0.0 \%)$ were found in those seeds which were collected from government organization of Khanpur, and Haripur. Analysis of mean values revealed that pea seeds collected from government organization of Khanpur contains highest amount of seed purity (98.4\%) followed by pea seed collected from government organization of Haripur (96.3\%), while lowest percentage of seed purity were found in pea seed collected from farmers of Haripur (78.8\%).

These results were in accordance with findings of [5, 15-17]. The result indicated that farmer saved seed was not of good quality because of presence of stones and dust particles. Thus the presences of these materials in farmer saved seed possess risk of contamination of field. This difference in results revealed that the technique of seed harvesting and cleaning adopted by farmers fails to remove properly unwanted particles from the harvested seed. On the other hand, Government Organization utilizes modern techniques for the removal of stones and dust particles that is the reason of government organization seeds with low amount of unwanted materials [18]. Government organization seed showed the highest percentage of viability because government organization seed was developed by using good quality seed having high standards with high germination rate. Government organization develops healthier and improved seed for better productivity. On the other hand, farmer and dealer seeds were not up to mark of government organization seed and developed through old cultural and management practices thus their viability was recorded low as compared with the government seed [19]. These results were inline with the findings of [18] Government organization collected seeds had less amount of other variety seed due to excellent cleaning and selection methods and management practices. Government organization makes this possible to remove all unwanted materials from the seeds by the use of new technologies. On the other hand, farmers were not able to utilize new technologies and utilize local techniques for the selection and cleaning of seed. Thus contain a large amount of other variety seed as compared to government organization seed [20]. Farmers and dealer's seeds were contaminated with a large amount of other crop seed due to impurity as both of them continuously utilized the local cultural and management practices of selection, growing, harvesting and cleaning of the seed. Thus the seed obtained was impure and contain other crop seed with it and stored for the next season. On the other hand, government organization seeds were founded with the fewer amounts of other crop seed as it was pure seed and developed through modern techniques [21]. [5] Also found significant differences among all the groups of seed sources and location. The results suggested that pea seeds which were collected from government organization of Khanpur, Haripur and Ghazi contains highest amount of seed purity as it belonged from government organization. Government organization seed was pure because it developed from high yielding and 
good quality parent varieties. Government organization seed was pure due to the fact that it developed from different stages and impurities were removed through each and every stage it passed [22, 23].

Table 3. Mean and LSD values of treatment for stone and dust particles, viability, other variety seeds, other crop seeds and seed purity

\begin{tabular}{|c|c|c|c|c|c|}
\hline $\begin{array}{c}\text { Seed } \\
\text { Sources }\end{array}$ & $\begin{array}{c}\text { Stone and dust } \\
\text { Particles }(\%)\end{array}$ & Viability (\%) & $\begin{array}{c}\text { Other Variety } \\
\text { Seed }(\%)\end{array}$ & $\begin{array}{c}\text { Other Crop } \\
\text { Seeds }(\%)\end{array}$ & $\begin{array}{c}\text { Seed Purity } \\
(\%)\end{array}$ \\
\hline $\mathrm{T} 1$ & $23.3 \mathrm{~b} \pm 2.8$ & $68.3 b c \pm 7.1$ & $1.34 \mathrm{a} \pm 0.07$ & 0.00 e \pm 0.0 & 86.3 ef \pm 3.7 \\
\hline $\mathrm{T} 2$ & $17.0 \mathrm{~cd} \pm 4.0$ & $69.6 b \pm 9.7$ & $0.26 \mathrm{e} \pm 0.03$ & $0.00 \mathrm{e} \pm 0.0$ & $91.9 \mathrm{~cd} \pm 1.3$ \\
\hline $\mathrm{T} 3$ & $9.00 \mathrm{e} \pm 1.0$ & $84.3 \mathrm{a} \pm 3.2$ & $0.00 \mathrm{f} \pm 0.00$ & $0.00 \mathrm{e} \pm 0.0$ & $98.4 \mathrm{a} \pm 0.7$ \\
\hline T4 & $27.6 \mathrm{ab} \pm 3.1$ & $58.6 \mathrm{~cd} \pm 6.5$ & $0.32 \mathrm{~d} \pm 0.03$ & $0.00 \mathrm{e} \pm 0.0$ & $78.8 \mathrm{~g} \pm 2.1$ \\
\hline T5 & $21.6 b c \pm 4.0$ & $60.3 \mathrm{bcd} \pm 10$ & $0.00 \mathrm{f} \pm 0.00$ & $0.33 \mathrm{c} \pm 0.08$ & $91.2 \mathrm{~cd} \pm 1.3$ \\
\hline T6 & $8.33 \mathrm{e} \pm 3.0$ & $87.33 \mathrm{a} \pm 7.7$ & $0.00 \mathrm{f} \pm 0.00$ & $0 \mathrm{e} \pm 0$ & $96.3 \mathrm{ab} \pm 2.2$ \\
\hline $\mathrm{T} 7$ & $32.3 \mathrm{a} \pm 6.1$ & $55.33 \mathrm{~d} \pm 3.5$ & $0.64 \mathrm{~b} \pm 0.04$ & $0.58 \mathrm{~b} \pm 0.02$ & $82.9 \mathrm{f} \pm 3.2$ \\
\hline T8 & $22.0 \mathrm{bc} \pm 3.6$ & $63.33 \mathrm{bcd} \pm 5.5$ & $0.43 c \pm 0.04$ & $0.11 \mathrm{~d} \pm 0.04$ & $89.5 \mathrm{de} \pm 0.8$ \\
\hline T9 & $14.0 \mathrm{de} \pm 3.6$ & $83.66 \mathrm{a} \pm 4.0$ & $0.00 \mathrm{f} \pm 0.0$ & $5.65 \mathrm{a} \pm 0.11$ & $94.1 b c \pm 1.7$ \\
\hline
\end{tabular}

organization of Khanpur T4: pea seed collected from farmer of haripur, T5: pea seed collected from dealer of Haripur, T6: pea seed collected from government organization of Haripur, T7: pea seed collected from farmer of Ghazi, T8: pea seed collected from dealer of Ghazi, T9: pea seed collected from government organization of Ghazi

\section{Conclusion}

From current study it can be concluded that seed collected from Government organizations of Khanpur, Ghazi and Haripur have proven to be suitable seed source as compared to those seeds collected from dealers in terms of less damaged kernel, inert matter, moisture content, germination percentage, purity percentage, seedling vigor index, insects and pest damaged seeds, other variety seed and have less stone and dust particles, whereas seed collected from farmers were of inferior quality and failed to produce desirable results. Hence from this study it is recommended that; Seed collected from Khanpur region possess best seed quality traits; Seed collected from three different sources i.e. Government organization, Dealers and Farmers; the seed quality of Government organization possess desirable seed quality for better yield; Majority of pea farmers usually grow their own seed or collect from local dealer which has inferior quality, hence it is recommended that Government should regularize the business and distribution of pea seeds in district Haripur. It is also recommended that pea farmers of district Haripur should be trained to use lasted techniques of seed storage to minimize the economic losses caused due to inferior quality seeds.

\section{Authors' contributions}

Conceived and designed the experiments: MI Khan, Q Ayub \& SM Khan, Performed the experiments: MI Khan, Analyzed the data: SU Rehman \& NU Haq, Contributed materials/ analysis/ tools: SHR Shah \& I Hussain, Wrote the paper: SU Rehman.

\section{References}

1. Ali I, Rab A \& Hussain SA (2002). Screening of pea germplasm for growth, yield and resistance against powdery mildew under the agro-climatic conditions of Peshawar, Pakistan. SJA 32(3): 455-460.

2. Rogers S (2007). Man and the Biological World Read Books. 169-170: ISBN 978-1-4067, 3304-4.

3. Nawab NN, Subhani GM, Mahmood K, Shakil Q \& Saeed A (2008). Genetic variability, correlation and path analysis studies in garden pea (Pisum sativum L.). Acad J Agric Res 46(4): 333-340.

4. Santalla M, Amurrio JM, \& De-Ron AM (2001). Food and feed potential breeding 
value of green, dry and vegetable pea germplasm. Can. J. plant sci 81(4): 601610.

5. Khan TN, Ramzan A, Jillani G \& Mehmood $\mathrm{T}$ (2013). Morphological performance of peas (Pisum sativum) genotypes under rain fed conditions of Potowar region. Acad J Agric Res 51(1): 51-60.

6. Hussain SA \& Badshah N (2002). Study on the adaptive behavior of exotic pea (Pisum sativum $L$.) varieties under local conditions of Peshawar. Asian J Plant Sci 1(5): 632634.

7. Kakar AA, Saleem M, Shah R \& Shah SQ (2002). Growth and marketable green pod yield performance of pea (Pisum sativum $L$.) under varying levels of NPK fertilizers. Asian J Plant Sci 1(5): 532-534.

8. Mason LJ \& McDonough M (2012). Biology, behavior, and ecology of stored grain and legume insects. Stored prod Protect 1(7): 145-156.

9. Steel RGD, Torrie JH \& Dickey DA (1997). Principles and Procedures of statistics: A Biometrical Approach, 3rd ed., McGraw Hill Book co., NewYork, USA.

10. Smith RS (1992). Legume inoculant formulation and application. Can $J$ Microbiol 38(6): 485-492.

11. Habibur R, Sattar A, Salim MR, Quddus A \& Ali M (2017). Study on Quality of Okra (Abelmoschus esculents L.) Seed Collected from Different Sources and Locations of Bangladesh. Am J Plant Sci 2(4): 129-135

12. Rachie KO \& Gardner CO (1975). January. Increasing efficiency in breeding partially out crossing grain legumes. In Inter Workshop on Grain Legumes 4(2): 13-16.

13. Thompson JA (1960). Inhibition of nodule bacteria by an antibiotic from legume seed coats. Nature 187(4737): 619-625.

14. Razzaque MA (1980). Farm level storage of wheat seeds. Paper presented at the postproduction workshop on food grains,
December 12-14. Workshop sponsored by the Food Sci. and Tech. Div. BCSIR, Dhaka.

15. Rahman MS, Hossain I \& Mansur MA (1985). Effect of storage condition on the quality of wheat seed. Bangladesh J Agril Sci 12(1): 49-54.

16. Raajasubramanian D, Sundaramoorthy $P$, Baskaran L, Ganesh KS, Chidambaram AA \& Jeganathan M (2011). Effect of cement dust pollution on germination and growth of groundnut. Int Multidiscip Res $J$ 1(1): 135-143.

17. Vaughan CE \& Delouche JC (1960). January. Relation of rate of seed swelling to viability in small seeded legumes. In Proceedings of the Association of Official Seed Analysts 50(1): 109-111.

18. Silvertown JW (1984). Phenotypic variety in seed germination behavior: the ontogeny and evolution of somatic polymorphism in seeds. Amer Nat 124(1): 1-16.

19. Buchbjerg E \& Madsen RF (1987). U.S. Patent No. 4,677,065. Washington, DC: U.S. Patent and Trademark Office.

20. Ramos ME, Robles AB, Ruiz-Mirazo J, Cardoso JA \& González-Rebollar JL (2006). Effect of gut passage on viability and seed germination of legumes adapted to semiarid environments. Grassland Productivity.

21. Siddhuraju P \& Becker K (2001). Species/variety differences in biochemical composition and nutritional value of Indian tribal legumes of the genus Canavalia. Food Nahrung 45(4): 224-233.

22. Rochester IJ, Peoples MB, Constable GA \& Gault RR (1998). Faba beans and other legumes add nitrogen to irrigated cotton cropping systems. Aust J Exp Agric 38(3): 253-260.

23. Kirkbride JH, Gunn CR, Weitzman AL \& Dallwitz MJ (2000). Legume (Fabaceae) fruits and seeds. Parkway Publishers, Incorporated. 